2011

\title{
Considering Pathological Altruism in the Law from Therapeutic Jurisprudence and Neuroscience Perspectives
}

Michael L. Perlin

New York Law School, michael.perlin@nyls.edu

Follow this and additional works at: https://digitalcommons.nyls.edu/fac_articles_chapters

Part of the Law and Psychology Commons, and the Medical Jurisprudence Commons

\section{Recommended Citation}

Perlin, Michael L., "Considering Pathological Altruism in the Law from Therapeutic Jurisprudence and Neuroscience Perspectives" (2011). Articles \& Chapters. 1227.

https://digitalcommons.nyls.edu/fac_articles_chapters/1227 


\section{CONSIDERING PATHOLOGICAL ALTRUISM IN THE LAW FROM THERAPEUTIC JURISPRUDENCE AND NEUROSCIENCE PERSPECTIVES}

Michael L. Perlin

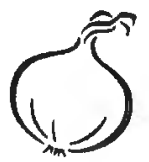

\section{KEY CONCEPTS}

- Therapeutic jurisprudence and neuroimaging are valuable tools when considering the treatment of pathological altruism in the law, in cases of organ donations to strangers and cases raising "cultural defenses."

- Therapeutic jurisprudence gives us a benchmark by which we can assess whether the pathological altruist (if, indeed, the altruist is pathological) has sacrificed her dignity to do the putatively pathologically altruistic act, an assessment process that can also illuminate whether the underlying behavior is irrational, harmful to others, or self-harming.

- Neuroimaging gives us new tools to potentially assess whether the pathological altruist is a rational moral agent in doing such acts.

ONE OF THE most important legal theoretical developments of the past two decades has been the creation and dynamic growth of therapeutic jurisprudence (see e.g., Wexler 1990, 2008; Wexler \& Winick, 1996; Winick, 2005). Initially employed in cases involving individuals with mental disabilities, but subsequently expanded far beyond that relatively narrow area, therapeutic jurisprudence presents a new model for assessing the impact of case law and legislation, recognizing that, as a therapeutic agent, the law that can have therapeutic or antitherapeutic consequences. The ultimate aim of therapeutic jurisprudence is to determine whether legal rules, procedures, and lawyer roles can or should be reshaped to enhance their therapeutic potential, while not subordinating due process principles (Perlin, 2003a, 2005, 2008). 
Therapeutic jurisprudence "asks us to look at law as it actually impacts people's lives" (Winick, 2009, p. 535) and focuses on the law's impact on emotional life and psychological well-being (Wexler, 2000, in Stolle, Wexler, \& Winick, 2000). In recent years, scholars have considered a vast range of topics through a therapeutic jurisprudence lens, including, but not limited to, all aspects of mental disability law, domestic relations law, criminal law and procedure, employment law, gay rights law, and tort law (Perlin, 2002-2003). As Ian Freckelton has noted, "it is a tool for gaining a new and distinctive perspective utilizing socio-psychological insights into the law and its applications" (Freckelton, 2008, p. 582).

One of the central principles of therapeutic jurisprudence is a commitment to dignity. Ronner describes the "three Vs": voice, validation, and voluntariness (2008, p. 627), arguing:

What "the three $\mathrm{Vs}$ " commend is pretty basic: litigants must have a sense of voice or a chance to tell their story to a decision maker. If that litigant feels that the tribunal has genuinely listened to, heard, and taken seriously the litigant's story, the litigant feels a sense of validation. When litigants emerge from a legal proceeding with a sense of voice and validation, they are more at peace with the outcome. Voice and validation create a sense of voluntary participation, one in which the litigant experiences the proceeding as less coercive. Specifically, the feeling on the part of litigants that they voluntarily partook in the very process that engendered the end result or the very judicial pronunciation that affects their own lives can initiate healing and bring about improved behavior in the future. In general, human beings prosper when they feel that they are making, or at least participating in, their own decisions. (Ronner, 2002, pp. 94-95; see generally, Ronner, 2010)

At the same time, legal scholars have also turned their attention to the relationship between neuroscience and the law, mostly in the context of criminal law and procedure, but also in civil matters such as trauma suffered by victims of brain injuries, testamentary capacity disability claims, toxic tort exposure, and the relationship between violent behavior and video games (Moriarty, 2008; Perlin, 2009b, 2009c). Scholars have begun to investigate (by way of an example to which I will return in a later part of this chapter) the relationship between brain functioning and the nature of human aggression (Archer, 2009; Siegel \& Victoroff, 2009):

Articles by legal scholars about altruism-related issues encompass civil and criminal law, as well as private and public law. Topics include, but are not limited to, cases involving organ donation law ${ }^{1}$ and the potential exculpatory impact of sociobehavioral syndromes known as "cultural defense cases" on criminal responsibility (these are further described in the section "Cultural Defenses and Pathological Altruism"). The altruism in these cases may potentially be characterized as posing questions of pathological altruism. ${ }^{2,3}$

In this chapter, I will first discuss the basic principles of therapeutic jurisprudence, which then leads to consideration of the relationship between neuroimaging and the law. ${ }^{4}$ Then I will consider the connection between organ donation and pathological altruism, and subsequently, between a "cultural defense" and pathological altruism. This will lead to a discussion of the interplay between therapeutic jurisprudence and pathological altruism, and between neuroimaging 
and the law and pathological altruism. Finally, I will offer some modest suggestions for scholars and policy makers.

\section{Therapeutic Jurisprudence}

As previously mentioned, therapeutic jurisprudence seeks to enhance values of "voice, validation, respect, and self-determination" and "voluntary participation." Importantly, it accomplishes this task in an interdisciplinary manner. (Waldman, 2008). Wexler summarizes:

Generally, therapeutic jurisprudence looks at the traditionally underappreciated area of the law's impact on emotional life and psychological well-being. It recognizes that, whether we know it or not, whether we like it or not, the law is a social force with consequences in the psychological domain. Also, therapeutic jurisprudence examines the role of the law as a therapeutic agent and its enormous potential to heal. Therapeutic jurisprudence looks not merely at the law on the books but rather at the law in action-how the law manifests itself in law offices, client behavior, and courtrooms around the world. The underlying concern is how legal systems actually function and affect people. (Wexler, 2008, p. 20)

Much of therapeutic jurisprudence's strength comes from this commitment to dignity ${ }^{s}$ and the awareness of those who write from a therapeutic jurisprudence perspective of the potential for humiliation inherent in the legal process. Authors have contextualized therapeutic jurisprudence in a wide range of legal issues, including criminal prosecution (Winick, 2009), child abuse and neglect proceedings (Salisbury, 2005), involuntary civil commitments (Winick, 1999), law in relation to terrorism (Rotman, 2008), international human rights (Winick, 2002), Miranda warnings (Ronner, 2002), and problem-solving courts (Winick, 2003). Authors underscore that therapeutic jurisprudence upholds human dignity and rejects humiliation as a legal tool (Freckelton, 2008) and that it empowers participants in the legal process (King, 2009). As Bruce Winick tells us: "If people are treated with dignity... and generally treated in ways that they consider to be fair, they will experience greater satisfaction and comply more willingly with the ultimate outcome of the proceedings, even if adverse to them" (Winick, 2003, p. 1089).

Some of the most important criticism of therapeutic jurisprudence flows from what is perceived-incorrectly, in my view-as its willingness to subordinate civil libertarian concerns to therapeutic interests (Kahn, 2002). ${ }^{\circ}$ Indeed, some of the enthusiasm that therapeutic jurisprudence has engendered may flow implicitly from the assumption that therapeutic interests will take precedence over due process (that is, legal) interests. Wexler and Winick, however, stress that therapeutic jurisprudence cannot and must not "trump" civil libertarian interests (e.g., Perlin, 2000; Wexler, 1993), as for example by refusing to allow a competent but institutionalized individual to refuse the involuntary imposition of antipsychotic medication (see e.g., Perlin, 2005).

It makes sense, then, to consider this book's central topic, pathological altruism, through a therapeutic jurisprudence lens. In this way, we may better understand why people sometimes act, at least at first blush, to their own detriment. A therapeutic jurisprudence filter gives us clues both about the source of this behavior and how the legal system should construe it. Several scholars have considered the link between therapeutic jurisprudence and altruism in the past. 
For example, Susan Daicoff (1999) has argued that therapeutic jurisprudence is particularly well suited for lawyers with personality traits atypical of lawyers in general, such as altruism (see also, Perlmutter, 2005). But none have considered the interrelationship between therapeutic jurisprudence and pathological altruism until now. The question will be framed this way: To what extent does the sort of behavior that is at the core of these subject matters-a willingness to donate organs to strangers, or to passively allow a criminal assault on the part of a domestic partner-reflect (or reject) therapeutic jurisprudence's commitment to dignity and the "three Vs" - voice, validation, and voluntariness?

\section{Neuroimaging}

Although neuroimaging is fraught with uncertainties (Roberts, 2006, p. 266, n. 155), and the steps used in the production and presentation of neuroimaging evidence are not only not standardized but easily manipulated by a person with the knowledge of the technology (Reeves, Mills, Billick, \& Brodie, 2003), it is clear is that the existence of neuroimaging techniques has nonetheless changed the contours of the courtroom playing field (Perlin \& McClain, 2009a, pp. 5-6).

Proponents of neuroimaging characterize it as "an objective, non-invasive quantifiable image, which can provide useful information, especially when the clinical examination may otherwise be normal" (Baskin et al,, 2007, p. 247). Further, they argue that neuroscience seems "advanced enough to enter forensic psychiatry" (Witzel, Walter, Bogerts, \& Northoff, 2008, p. 115), and claim "advances in neurobiological research methods allow one to address the nature and biological basis of human behavior" (Muller et al., 2008, p. 131) Some of those skeptical about wider admissibility of neuroimaging evidence in the court process note that a "brain image is the vivid representation of anatomy or physiology through a pictorial or graphic display of data" (Reeves et al., 2003, p. 89), and fear that this vividness "might lead unwitting fact-finders to believe that the story told by the neuroimaging picture is susceptible to only one interpretation" (Perlin, 2009b, p. 890). Opponents of the wider admissibility of such testimony argue the ambition of cognitive neuroscientists is "to use the claims of their discipline and the new powers conferred by neuroimaging to overthrow retributive justice as a legitimate justification for criminal sanctions" (Snead, 2007, p. 1316), and that neuroimaging may be simply a "neo-phrenological fad." (Marks, 2007, p. 492, quoting Uttal, 2003). Jurors may be inappropriately swayed by what they perceive as the evidence's "nonfalsifiability"-because it appears to be vivid, objective, quantifiable, and advanced (Perlin, 2009b, 2009c). On the question of how neuroscientific evidence may inappropriately sway juries in insanity defense cases by leading them to focus on questions not relevant to the legal question before them, see Batts (2009).

There are other issues of importance in relation to neuroimaging evidence. Most important, from a legal perspective, is whether such evidence is admissible at a trial. In Daubert v. Merrill Dow Pharmaceuticals (1993), the Supreme Court ruled that jurors could hear evidence and weigh facts from experts whose testimony included novel scientific theories-even if those theories had not gained "general acceptance" in the scientific community-as long as the testimony was "relevant" and "reliable." In construing relevance and reliability, the Court specified consideration of five factors: (1) whether the expert's hypothesis has been tested, (2) whether peer review and publication of the methodology has occurred, (3) the frequency of erroneous results, (4) standards controlling 
the technique's operations, and (5) acceptance of the methodology in the scientific community.

Empirical studies have consistently demonstrated the stark disparity in judicial decision making in Daubert cases. In criminal cases, the prosecutor's position is sustained (either in support of questioned expertise or in opposition to it) vastly more often than is defense counsel's (Risinger, 2000, pp. 105-108). By way of example, in 67 cases of challenged government expertise, the prosecution prevailed in 61 . Out of 54 complaints by criminal defendants that their expertise was improperly excluded, the defendant lost 44 . Contrarily, in civil cases, $90 \%$ of Daubert appeals were by the defendants, who prevailed two-thirds of the time. ${ }^{8}$ 'This disparity must be kept in mind when we seek to "tease out" the ways that neuroimaging testimony will (or will not) be accepted as evidence at trial.

In an earlier paper on neuroimaging and the law, I sought to capture the ambivalence that surrounds the relationship between this evidence and the judicial process:

Neuroimaging is (or isn't) hard science. It is (or isn't) relatively easy for jurors to interpret. It is (or isn't) immune to falsification efforts. It is (or isn't) objective. It will (or won't) lead jurors to "better" verdicts in insanity cases. It will (or won't) be used disproportionately in Action News-friendly cases. It will (or won't) "trump" jurors' inherent suspicion of the insanity defense. It does (and here there is no contradictory or antipodal position) raise a variety of important and provocative legal, behavioral, and social issues, none of which has received nearly enough attention by the courts or by commentators. (Perlin, 2009b, p. 915)

How does this ambiguity apply to the matter at hand? Although some scholars have begun to examine how neuroscience advances may illuminate the roots of altruistic behavior ${ }^{9}$ there has so far, to the best of my knowledge, been no such focus on its relationship to pathological altruism. ${ }^{10}$ Although we are still barely at the speculative stage here, multiple questions arise: Might neuroimaging provide a better understanding of not only altruism, but also pathologies of altruism? ${ }^{11}$ Might it offer clues when a party alleges that a certain action was altruistically motivated, when, in fact, that might not be so? And, most importantly for these purposes, if neuroimaging does appear to offer these answers, and the testing in question is offered in a court proceeding, how will courts construe it? ${ }^{12}$

\section{Organ Donation and Pathological Altruism}

Michele Goodwin, one of the most prominent critics of the current organ donation system, charges that the altruistic model is socially taxed "beyond its capacity" (Goodwin, 2004, p. 308), that "altruism . . . is a losing battle" (p. 311; p. 311, n. 20), and concludes that "the success of altruism relies on the macabre" (p. 319) Other scholars have described the ethical propriety of academic scholarship programs that might stimulate the donation of organs by the living (Cherry, 2009; Graham \& Livingson, 2009; Linford, 2009).

The title of an article about the motivations of organ donors asks: "The Living Anonymous Donor: Lunatic or Saint?" (Henderson et al, 2003). The authors of the piece, which focused on kidney donations, note that some critics argue that such altruism "appears by definition as either irrational or pathological" (p. 203). ${ }^{13}$ The results of the authors' empirical study demonstrate that this is not the case: "there is a significant number of psychologically stable, altruistically 
motivated individuals who want to donate a kidney anonymously to a stranger and seek no material compensation in return" (p. 208). ${ }^{14}$ Yet, there is no question that many commentators consider such altruistic acts to reflect "a defensive cloak for sadomasochism," in some instances flourishing as "psychotic altruism, manifest[ing] in bizarre forms of ... behavior and associated self-denial based in delusion" (Baskin, 2009, p. 378). ${ }^{15}$

\section{Cultural Defenses and Pathological Altruism}

A cultural defense allows a defendant to seek a reduction in the level of a criminal charge because he was ostensibly acting according to his culture's norms and expectations in cases in which he may not have had time to assimilate or understand American cultural values (Goldstein, 1994; Suri, 2000). ${ }^{16}$ Although this defense has been offered on rare occasions as a form of insanity defense (thus making the claim of nonresponsibility), it is more often relied on in support of claims of mistake of fact, diminished capacity, "heat of passion," selfdefense, or in support of a reduced sentence (DePalma, 2009; Goldstein, 1994). ${ }^{17}$ Relevant to the context of this chapter are cultural defense claims raised in cases in which (1) defendants kill their unfaithful wives (or wives perceived to be unfaithful), and (2) mothers kill their children in response to spousal infidelity (Lee, 2007). ${ }^{18}$

This has led scholars to grapple with related questions of how the law should deal with (a) victims who voluntarily participate in activities that meet statutory criteria for criminality but might be acceptable behavior in the victim's native culture, ${ }^{19}$ where, perhaps, victims accept the "externalizing of blame" (Wang, 1996 , p. 156) or "subscribe . . to [the culture's] tenets" (Li, 1996, p. 787); ${ }^{20}$ and (2) defendants whose crimes are attributed to altruistic motives in this context. ${ }^{21}$ This literature should be read in tandem with the writings of feminist scholars such as Robin West, who suggest that the altruistic behavior we encourage in women is often a "gender-specific harm" (McClain, 2001, p. 1707, discussing West, 1997) and that we need to distinguish altruism rooted in care from altruism rooted in fear (Sheehan, 2000, p. 93, n. 37, discussing West, 1997, p. 123). ${ }^{22}$ These insights have led to great debates among scholars as to whether the cultural defense conflicts with or can stand aligned with the battered spouse syndrome (Suri, 2000; Volpp, 1994). ${ }^{23}$ In this context, Hannah Crockett has observed:

The cultural defense promotes stereotypes by reinforcing "false, anachronistic" images of a defendant's culture. The cultural defense "reinforces Western notions of a primitive, not quite autonomous 'other' who is too culture-bound to make reasoned judgments ... [D]iscussions of foreign cultures in the context of the defense assume those cultures to be static and rigid, unlike the presumably everchanging, fluid [dominant culture of the] West." The cultural defense, rather than counteracting prejudice, may actually promote contempt for minority culture groups. $(2006, \text { p. 684 })^{24}$

People v. Kimura (1985) has received great attention in the academic literature. In this case, a married Japanese-American woman in her $30 \mathrm{~s}$, the mother of a young child and an infant, intended to commit parent-child suicide (oyakoshinyu) after learning her Japanese-American husband had been keeping a mistress for many years. The children drowned, but the mother was rescued 
by a passerby. The prosecution charged her with first-degree murder. However, the Japanese-American community petitioned the court to reduce the charge, emphasizing that parent-child suicide was at the root of her culture behavior, and she should be judged within the context of Japanese standards. (Perlin \& McClain, 2009a, 2009b; see Goel, 2004, p. 455; petitions with more than 25,000 signatures were submitted to the sentencing court). Her psychiatric diagnosis was "brief reactive psychosis," including major depression (Chiu, 2006, p. 1356, n. 156). As a result of input from both the experts and the community, the homicide was reduced to voluntary manslaughter and the defendant was sentenced to 1 year in custody and 5 years probation with psychiatric counseling recommended (Perlin \& McClain, 2009a). ${ }^{25}$

One commentator has discussed the Kimura case in the context of what she characterizes as "altruistic" filicide, the suicidal parent believing murder to be an altruistic act because she either cannot abandon the child or wishes to alleviate the child's suffering, either real or imagined (Wu, 2003, p. 1013, n. 277). Society's response to such cases may mirror that of infanticidal mothers who plead the insanity defense: "Unlike the typical insanity-pleading defendant (who fills jurors with fear and loathing), these defendants puzzle jurors: 'How could this defendant have committed such an inexplicable and irrational crime? She must have been crazy!' (Perlin, 2003, p. 19; see generally, Oberman, 2004). ${ }^{26}$ As Daina Chiu explains, women are "assumed to be inherently passive, gentle, and tolerant; and mothers are assumed to be nurturing, caring, and altruistic. It is an easy step, therefore, to assume that a 'normal' woman could surely not have acted in such a way" (Chiu, 1988, p. 1118).

These cases are perplexing to criminal law and procedure scholars for many reasons, not least of which because they involve conflicting stereotypes and conflicting heuristics. ${ }^{27}$ Several years ago, I wrote this in an article about the use of the insanity defense in infanticide cases (focusing especially on neonaticide cases):

This area of the law is especially incoherent even when compared to [other] insanity defense cases .... On one hand, we are especially punitive towards such defendants because they have violently violated our precepts of motherhood. On the other, we are more willing to find some of these defendants not guilty by reason of insanity than we are in cases involving almost any other kind of insanity pleader (again, almost in a way that imitates nullification verdicts) as a reflection of our desire to maintain an inviolate image of "mother love." (Perlin, 2003, p. 6)

The use of the cultural defense in cases involving pathological altruismeither in which the pathological altruist is the willing victim (as with an acquiescent wife in culturally sanctioned wife abuse) or the perpetrator (as with a woman killing her children to save them from shame, often caused by the perpetrator's husband's infidelity) - causes us to reconsider these conflicts. It forces us to confront how our preexisting sets of biases shape and distort our thinking and decision making in this area of law and social policy. It is another reason why we must now turn to therapeutic jurisprudence as a potential solution. ${ }^{28}$

\section{Therapeutic Jurisprudence and Pathological Altruism}

Interestingly, therapeutic jurisprudence scholars have underscored the relationship between therapeutic jurisprudence and altruism, and contrarily, the disconnect between altruism and the law-and-economics model (Slobogin, 1995, p. 95). ${ }^{29}$ 
Miller argues that therapeutic jurisprudence "legitimizes preventive law by providing it with an altruistic motivation" (Miller, 2009, p. 275; see also Stolle et al., 2000); Shuman questions whether "plaintiffs experience a sense of altruism based upon a belief that the lawsuit has prevented this injury from happening to others?" (Shuman, 1993, p. 756; see also, Binder, Trimble, \& McNiel, 1991). Daicoff uses psychological data on the personality traits of lawyers to argue that therapeutic jurisprudence is particularly well suited for lawyers with altruistic personality values (Daicoff, 1999; see also Shuman, 1993). ${ }^{30}$ But there is no mention in the therapeutic jurisprudence literature about its relationship -if there is one-to pathological altruism, and about what it might have to say about behavior reflecting the "willingness of a person to irrationally place another's perceived needs above his or her own in a way that causes self-harm." It is considered, interestingly, in Goodwin's work on organ donation, which argues that "dignity, trust, and autonomy [not altruism] are the more relevant values to be preserved and promoted in organ transplantation" (Goodwin, 2009, p. 34).

A related issue is whether organs may ever be harvested from persons who are, at the time, legally incompetent. One author has concluded that such harvests should be "categorically prohibited" (Cheyotte, 2000, p. 469). ${ }^{31}$ Similar issues are raised in cases involving donations by adolescents (Hartman, 2008). There is an important parallel here in the discussion of whether a person of fluctuating competency ${ }^{32}$ is capable of giving informed consent to biomedical research. Bruce Winick has noted:

Another potential use for advance directive instruments is in the area of participation in biomedical or behavioral research. Under ethical and legal requirements for human experimentation, the informed consent of the individual is required and consent may be revoked at any time. This latter requirement may be problematic for people suffering from mental disorders that cause fluctuating periods of incompetency. Should such individuals, therefore, be barred from participation in research? Can they enter into advance directive instruments agreeing to participate in research and appointing surrogates who can revoke their consent to participate on their behalf during a period of incompetency? If so, what safeguards need to be built into such advance directive instruments so that they may protect the rights of research participants and allow investigators to accept their participation consistent with ethical and legal requirements? (Winick, 1998, p. 602)

To what extent, then, does the sort of pathological altruism that is reflected in "stranger" organ donation cases or in cultural defense cases honor Ronner's principles of therapeutic jurisprudence- "voice, validation, and voluntariness"? Empirical studies of such donations suggest they are empowering for many of the donors (for discussions, see Henderson et al., 2003; Landolt et al., 2001; Spital, 2001), as long as the donor is competent to make the donation decision on his or her own (Cheyotte, 2000; Henderson et al, 2003; Winick, 1998). Such behavior, then, might not be "irrational" under my definition, and might not, under that definition, "interfere with rational social behaviors." 34

On the other hand, it is much more difficult to find a therapeutic jurisprudence basis for the behaviors of acquiescent victims in the cultural defense cases. If Patricia Hernandez is correct when she states that victimization reflects "the cross that God has sent me"(2003, p. 865), and if this putatively altruistic behavlor is regularly rooted in fear (e.g., Sheehan, 2000; West, 1997), then it appears 
that the dignity that is a core underpinning of therapeutic jurisprudence (e.g., Winick, 2003, p. 1089) is wholly absent in this self-harming and irrational behavior.

\section{Neuroimaging and Pathological Altruism}

Neuroimaging may offer important insights into the neural roots of empathy and trust (DeMartino, Kumaran, Seymour, \& Dolan, 2006; Shirtcliff et al., 2009) and the biological bases of both human decision making (Knabb, Welsh, Ziebell, \& Reimer, 2009) and moral judgments (Green et al., 2001). Scholars and researchers have made significant progress in employing neuroimaging tools to learn more about the etiology of altruism. ${ }^{35}$ Some go as far as to say that, from an anthropological perspective, neural "wiring" makes some decision making inevitable (Schreiber, 2009). Recent research argues that functional magnetic resonance imaging (fMRI) scans can be strongly predictive of a person's likelihood for altruistic behavior (Parker, 2007), and that positron emission tomography (PET) scans indicate a signature reflective of the decision of game players to mete out altruistic punishments to cheaters (Parker, 2004).

It appears reasonably certain that neuroimaging is capable of revealing some of the roots of altruistic behavior. But this leads to another question: To what extent would such evidence be admissible in court proceedings that relate to the underlying issues? On the surface, neuroimaging might illuminate competency issues that are relevant to some organ donation questions, as well as mental state issues that are relevant to some cultural defense questions (on the need for those doing neuropsychological forensic assessments to be culturally competent, see Judd, 2005; on how the expanded use of neuroimaging techniques "manifest larger cultural concerns about . . . medical expertise," see Aggarwal, 2009, p. 241). However, as mentioned earlier, there are ongoing threshold obstacles to the introduction of neuroimaging evidence, and it is not at all clear that, in the decision making process, courts are rendering their decisions in bias-free ways (Perlin, 2009c; Risinger, 2000; Rozelle, 2007). On this point, then, my conclusion is simply that, although I believe that neuroimaging might have much to tell us about the root causes of some behaviors of some pathological altruists, we may not yet be at the point at which the legal system is ready to embrace such testimony.

Therapeutic jurisprudence gives us a benchmark by which we can assess whether the pathological altruist (if, indeed, the altruist is pathological) has sacrificed her dignity to do the putatively pathologically altruistic act, an assessment process that can also illuminate whether the underlying behavior is irrational or self-harming.

\section{Conclusion}

Both therapeutic jurisprudence and neuroimaging are valuable tools when considering the treatment of pathological altruism in the law, in the scenarios discussed in this chapter. Therapeutic jurisprudence gives us a benchmark by which we can assess whether the pathological altruist (if, indeed, the altruist is pathological) has sacrificed her dignity to do the putatively pathologically altruistic act, an assessment process that can also illuminate whether the underlying behavior is irrational or self-harming. Neuroimaging and neuroscience give us new tools to potentially assess whether the pathological altruist is a rational moral agent in doing 
such acts. These tools may help illuminate our further and deeper understanding of these issues, and may give us new insights into why people do engage in such actions even when they appear to be self-defeating as well as selfdestructive.

A robust body of therapeutic jurisprudence literature has grown over the past two decades (see Perlin \& Cucolo, 2009, \$2D -4, listing articles), and in the past several years, scholars have begun to grapple with the full range of issues related to the use of neuroimaging evidence in the court system (see Perlin, 2009b, 2009 c, citing articles). Yet, there has been virtually no attention paid to the issues that I seek to address in this chapter. My hopes are that scholars who write and do empirical research in both fields will now turn their focus to these questions in an effort to illuminate some of the underlying issues.

In my writings about the insanity defense, I have always tried to focus on the perplexing question of "why do we feel the way we do about these people?" (e.g., Perlin, 1999, p. 17, referring to those who plead the insanity defense). More recently, in a piece on neuroimaging and the law, I noted difficulties in the criminal justice process involving cases of "defendants with mental disabilities who commit, on-the-surface, inexplicable acts" (Perlin, 2009b, p. 909). To many of us, the acts committed by those discussed in this chapter-stranger organ donors and cultural defense pleaders/victims-are equally inexplicable, with an inexplicability that is intertwined with both societal and judicial stereotypes (see Maguigan, 1995, p. 66, n. 103). I believe that the application of the therapeutic jurisprudence lens and filter ${ }^{36}$ to these cases will make the debate far richer, and that if neuroscience scholars turn their attention to these questions, we may have increasing confidence in the fairness of the disposition of cases involving these issues.

\section{Acknowledgments}

The author wishes to thank David Wexler for his helpful comments and suggestions, Naomi Weinstein for her impeccable research assistance, and Barbara Oakley for her superb editorial suggestions. He is saddened that Bruce Winick, who offered so much aid and encouragement, did not live to see the publication of this volume.

\section{Notes}

1. See Part IV. A recent simple WESTLAW search of "organ donation" in the ALLCASES database yielded a total of 136 cases (search conducted December 15, 2009).

2. For a historical review of the psychoanalytic explanation of pathological altruism, see McWilliams (1984). For subsequent consideration, see Seelig and Rosof (2001).

3. For the purposes of this chapter, I am adopting a modified version of pathological altruism used elsewhere in this volume by Michael MoGrath and Barbara Oakley: I define it as the willingness of a person to irrationally place another's perceived needs above his or her own in a way that causes self-harm, Put another way, it involves an excessive expression of empathy demonstrated in ways that can interfere with rational social behaviors (Eisenberg, 1984).

4. On the potential relationship between therapeutic jurisprudence and neuroimaging, see Perlin (2009a).

5. On how therapeutic jurisprudence presupposes the protection of and shares the values of dignity, see Rotman (2008); on its use as a tool for the restoration of dignity, see Salisbury (2005) and Perlin (2009a). 
6. For example, see Petrila (1993, p. 893) discussing "the assumption that in virtually all circumstances the legal system should defer to the prescriptions of treaters"-in other words, that courts should be exceedingly deferential to institutional decision making in cases involving persons residing in psychiatric facilities.

7. Daubert was decided under the Federal Rules of Evidence and is binding in all federal cases. In addition, many states have chosen to follow Daubert's guidance. Other states continue to adhere to the earlier rule set down in Frye v. United States (1923) allowing judges to exclude evidence from expert witnesses if it has not been "generally accepted."

8. Susan Rozelle is blunt: "The game of scientific evidence looks fixed" (2007, p. 598).

9. Ben Seymour and his colleagues, by way of example (2007, p. 309), posit that altruistic punishment is a strategy employed by humans to promote the cooperation needed for the maintenance of human societies. Stacey Tovino (2007, p. 418) asks, "Can fMRI reveal whether an individual is racially prejudiced, deceitful or altruistic?"; see also generally, Kuklin (2008).

10. For a parallel inquiry into the relationship of the Daubert test to the admissibility of transcranial magnetic stimulation (TMS) evidence in deception detection, see Luber et al. (2009).

11. On the question of whether there is a genetic predisposition for altruism, see Knafo et al. $(2007,2009)$. On the mechanisms of cultural transmission that result in "positive selection pressures on rules mandating beneficent behaviors," see Allison (1992-1993, p. 295).

Scholars have also begun to explore the religious roots of excessive altruism (Wilson, 2007 ) and the patriotic roots of manipulated altruism (Rushton, 1989, p. 516). On altruism exemplified by actions based on a sense of duty and moral obligation, see Harrison (1986, p. 1326).

12. This is especially relevant in that it is unclear that neuroimaging results in these cases would meet the teleological preconceptions of the factfinder (see Perlin, 1994, p. 262): “The legal system selectively-teleologically-either accepts or rejects social science evidence depending on whether or not the use of that data meets the a priori needs of the legal system"; see generally, Appelbaum (1987). On how therapeutic jurisprudence might combat the inappropriate use of teleology by courts in insanity defense cases (see Perlin, 2009b, p. 913).

13. Cf. Rushton (1989, p. 503), who notes: "In extreme form, altruism involves self-sacrifice."

14. See also Baskin (2009) on the positive value of altruistic donation, and Schwartz et al. (2003), describing how altruistic social behaviors are positively associated with better mental health. Henderson and his colleagues conclude that the evidence is "sufficiently compelling to consider developing [anonymous donor] programs nationally and internationally" (Baskin, 2009, p. 208; Henderson, 2003). Other studies reveal that about a quarter of surveyed respondents would be willing to donate a kidney to a stranger (Landolt et al., 2001, p. 1694 [29\%]; Spital, 2001, p. 1061 [24\%]). Other research suggests that donors may be motivated by a heightened altruistic sense of civic duty (see Blumkin \& Margalioth, 2008).

15. For the standard psychoanalytic interpretation of the narcissistic bases of such altruism, see Seelig and Rosof (2001) and Garrett(1983); on the putatively altruistic acts that reflect "self-loathing," see Jansen (2009, p. 27); on the psychological roots of some "selfish altruism," see Shapiro and Gabbard (1994) and Atkinson (1999); for altruism's relationship to social Darwinism, see Goodenough (2006). 
On the specific role of religious-based altruism in the "Jesus Christian" religious commünity, see Mueller et al. (2008); on religion and altruism more generally in this context, see Dixon and Abbey (2000).

16. Certain "culture-bound syndromes" are included in the American Psychiatric Association's Diagnostic and Statistical Manual of Mental Disorders. For a discussion in this context, see King (1999).

17. On the relationship between the cultural defense and the "ignorance of the law defense," see Power (2007, discussing the defense's potential application to cases from the Pitcairn Islands involving sex with minors).

18. Omitted from this chapter for reasons of space is the third category discussed by Professor Lee, men who claim "marriage by capture" as part of the Hmong tradition. See generally, Evans-Pritchard and Renteln (1995); see also Goel (2004, p. 457, n. 59), discussing People v. Moua (1985) (finding defendant guilty of forcible confinement rather than kidnapping and rape based on the traditional Hmong practice of marriage by capture; defendant argued that he mistook the victim's resistance for the ritual resistance required by the traditional ceremony, and therefore reasonably believed that the victim was actually consenting). Cynthia Lee (2007, p. 959) argues "the persuasiveness of a defendant's cultural claims may turn on the extent to which the claims converge with the dominant subtexts of racism and sexism."

19. See Harvard Note (1986, p. 1309): "A cultural defense should more readily be admitted when the crime is limited to persons capable of meaningful consent who belong to that culture and subscribe to its tenets"; see also Villareal (1991).

20. See Goozner (1994) quoting the director of a Japanese psychiatric research institution, who characterizes battered Japanese women as being afflicted with "pathological altruism." Hernandez (2003, p. 865) argues that, in Latin American culture, domestic violence victimization often leads to acceptance as "the "cross that God has sent me."

21. For example, see Wu (2003, p. 1013, n. 277): "The most common motive for parents killing their children was what the parent believed to be altruism: the suicidal mother or father who thinks that they cannot abandon the child, or who kills to alleviate the child's suffering, whether real or imagined."

22. Notes West (1997, p. 119): "Women's inclination toward private or intimate altruism-particularly in the home-is also, many times, and in many ways, the measure of the harms such women have distinctively sustained." See McClain (1999, p. 499), discussing West (1997, p. 119), describing how women's altruistic acts are often driven by "fear and insecurity." On how women are expected to be more altruistic than are men, see West (1997, p. 109; see also, West, 1988, discussed in Kell, p. 367, n. 64). On how women are assigned a "disproportionate responsibility for care," see McClain (2001, p. 1707).

23. Compare Lee (2007, p. 939: "successful cultural defenses often reinforce racial or ethnic stereotypes"), to Renteln (2004, p. 65: "A serious objection to the cultural defense is the worry it will reinforce stereotypes about groups. It is important that the cultural question be handled with sensitivity, so that the case does not convey the erroneous impression that just because one individual followed a tradition, everyone within a particular cultural community behaves in a way that violates the law"). For a comprehensive defense of the cultural defense, see Renteln (1993).

24. On how the use of such a defense can pathologize cultural difference, see Tseng, Matthews, and Elwyn (2004, pp. 181-182).

25. See generally, Lee (2007), Goldstein (1994), Goel (2004), Hoeffel (2006, p. 331), MacGuigan (1995); see also Wu (2003, p. 1002, n. 192), discussing the infanticide case of People v. Wu (1991), and see id. at p. 1015, n. 290, suggesting the link between immigrant mothers in Southern California who killed their children was not culture, but rather 
that they "suffered depression from pressure and stress of adjusting to a new life in a new land."

26. On the impact of psychosis on maternal filicide, see Lewis and Bunce (2003).

27. See Perlin (2009a, p. 887, footnote omitted):

Thus, when we consider ... the impact of neuroimaging evidence on juror decision making in insanity defense cases[,] we need to recalibrate our focus so as to incorporate other questions that are as essential (most likely more essential) to the resolution of the underlying dilemma: ... (2) will [the] "falsifiability issue" even matter to jurors whose personal values/moral codes reject the notion of any non-responsibility verdict because it is dissonant with their heuristics-driven, false ordinary common sense"[?]

28. See Perlin (2010, on the use of therapeutic jurisprudence as a tool to remedy the incoherence of the insanity defense.

29. Compare Brady (2008, p. 559) who argues that law and economics "largely ignores altruism," with Menkel-Meadow (1992, p. 387), who describes the proscriptions and prescriptions of the codes of lawyers' ethical conduct as antithetical to the ethos of therapeutic jurisprudence. On how judicial altruism flies in the face of the rational choice approach associated with law and economics, see Stout (2002 p. 1610).

30. See also Landsman and McNeel (2004), who note that preference for altruistic law practice predicts law students' moral judgment scores; Chamlin and Cochran (1997) describe the beneficent behaviors of social altruism; Ronel et al. (2009) write on the significance of perceived altruism.

31. See Cheyotte (2004, p. 508): "Imputing the psychological benefits of altruistic behavior to individuals who, because of age, cognitive ability, and circumstances cannot make altruistic choices, is myopic." For a fascinating dialogue on the consideration and construction of competency in an altruistic organ donation case, compare Spike (1997) to Silverman (1997).

32. Competency is not a fixed state but may fluctuate as a natural course of an individual's illness, or in response to treatment or psychodynamic factors (Johns, 2004).

33. Compare this with Yuille $(2007,392, n .5)$, who notes: "The concept of 'altruistic pathology' is meant to distinguish between the moral, social, and legal norms that pathologize outsider groups for the purpose of - or that have the effect of enablingoppression and the pathology that characterizes outsiders' abnormality as a justification for special, supposed positive treatment."

34. On the related question of the rationality of appearance-enhancing cosmetic surgery, see for example Ruel (2007, p. 125, quoting, in part, Sullivan, 2000, p. 28):

Whether a woman elects cosmetic surgery because of the social norms expressed in centerfolds, swimsuit issues, or the workplace, the inescapable conclusion remains that the decision is "a rational response to prevailing cultural values that reward those considered more attractive" and penalizes the ugly or less attractive.

35. For example, see Damasio (2007) and Tankersley et al. (2007). For the neural bases of altruism, see Rilling (2008, 2009).

36. See Perlin (2005, p. 754): "A therapeutic jurisprudence lens should regularly be applied to this entire area of the law, and courts should begin to consider the issues discussed here through a therapeutic jurisprudence filter." 


\section{References}

Aggarwal, N. K. (2009). Neuroimaging, culture, and forensic psychiatry. Journal of the American Academy of Psychiatry and Law, 37, 239-244.

Allison, P. D. (1992). The cultural evolution of beneficent norms. Social Forces, 71, 279-301. Appelbaum, P. (1987). The empirical jurisprudence of the United States Supreme Court. American Journal of Law Medicine, 13, 335-350.

Archer, J. (2009). The nature of human aggression. International Journal of Law and Psychiatry, 32(4), 202-208.

Atkinson, R. (1999). Liberating lawyers: Divergent parallels in "Intruder in the Dust" and "To Kill a Mockingbird." Duke Law Journal, 49, 601-748.

Baskin, J.H. et al. (2007). Is a picture worth a thousand words? Neuroimaging in the courtroom, American Journal of Law and Medicine, 33, 239-269.

Baskin, J. H. (2009). Giving until it hurts? Altruistic donation of solid organs. Joumal of the American Academy of Psychiatry and Law, 37, 377-379.

Baskir, C. E. (2009). Fostering cultural competence in justice system "gatekeepers." Judicature, 92, 232-237.

Batts, S. (2009). Brain lesions and their implications in criminal responsibility. Behavioral Sciences of Law, 27, 261-272.

Binder, R. Lo, Trimble, M. R., McNiel, D. E. (1991). Is money a cure? Follow-up of litigants. Bulletin of the American Academy of Psychiatry o Law, 19, 151-160.

Blumkin, T., \& Margalioth, Y. (2008). On terror, drugs, and racial profiling. International Review of Law of Economics, 28, 194-203.

Brady, K. L. (2008). The value of human life: A case for altruism. Natural Resources Journal, 48, 541-562.

Chamlin, M. B., \& Cochran, J. K. (1997). Social altruism and crime. Criminology, 35, 203-228.

Cherry, M. J. (2009). Embracing the commodification of human organs: Transplantation and the freedom to sell body parts. St. Louis University Journal of Health Law and Policy, 2, 359-377.

Cheyotte, C. (2000). Organ harvests from the legally incompetent: An argument against compelled altruism. Boston College Law Review, 41, 465-515.

Chiu, D. C. (1988). The cultural defense: Beyond exclusion, assimilation, and guilty libẹralism. California Law Review, 83, 1053-1125.

Chiu, E. M. (2006). Culture as justification, not excuse. American Criminal Law Review, 43, 1317-1374.

Crockett, H. Y. (2006). Cultural defenses in Georgia: Cultural pluralism and justice-can Georgia have both? Georgia State University Law Review, 22, 665-688.

Cruz, E. (2008). Through the clinical lens: A pragmatic look at infusing therapeutic jurisprudence into clinical pedagogy. Thomas Jefferson Law Review, 30, 463-485.

Daicoff, S. (1999). Making law therapeutic for lawyers: Therapeutic jurisprudence, preventive law, and the psychology of lawyers. Psychology, Public Policy \& Law, 5, 811-844.

Damasio, A. (2007). Neuroscience and ethics: Intersections. American Journal of Bioethics, 7,3-7.

Daubert v. Merrill Dow Pharmaceuticals, Inc., 509 U.S. 579 (1993).

DeMartino, B., Kumaran, D., Seymour, B., \& Dolan, R. (2006). Frames, biases, and rational decision-making in the human brain. Science, 313, 600-601.

DePalma, A. R. (2009). I couldn't help myself-my culture made me do it: The use of cultural evidence in the heat of passion defense. Chicana/o-Latina/o Law Review, 28, 1-18. 
Dixon, D. J. \& Abbey, S. E. (2000). Religious altruism and organ donation. Psychosomatics, 41, 407-411.

Evans-Pritchard, D. \& Renteln, A. D. (1995). The interpretation and distortion of culture: A Hmong "marriage by capture" case in Fresno, California. Southern California Interdisciplinary Law Journal, 4, 1-48.

Freckelton, I. (2008). Therapeutic jurisprudence misunderstood and misrepresented: The price and risks of influence. Thomas Jefferson Law Review, 30, 575-591.

Frye v. United States, 293 Fed. 1013 (D.C. Cir. 1923).

Garet, R. R. (1983). Communality and existence: The rights of groups. Southern California Law Review, 56, 1001-1075.

Goel, R. (2004). Can I call Kimura crazy?: Ethical tensions in the cultural defense. Seattle Journal of Social Justice, 3, 443-460.

Goldstein, T. F. (1994). Cultural conflicts in court: Should the American criminal justice system formally recognize a "cultural defense"? Dickinson Law Review, 99, 141-168.

Goodenough, O. (2006). Cultural replication theory and law: Proximate mechanisms make a difference. Vermont Law Review, 30, 989-1004.

Goodwin, M. (2004). Altruism's limits: Law, capacity, and organ commodification. Rutgers Law Review, 56, 305-407.

Goodwin, M. (2009). Confronting the limits of altruism: A response to Jake Linford. Saint Louis University Journal of Health Law \& Policy, 2, 327-345.

Goozner, M. (1994, July 24). Japan finally comes to grips with reality of domestic violence. Buffalo News, A4.

Graham, W. K., \& Livingston, J. P. (2009). Perspectives on financial incentives to induce live kidney donation: Scholarships in exchange for the gift of life. St. Louis University Journal of Health Law and Policy, 2, 347-358.

Greene, J. D., Sommerville, R. B., Nystrom, L. E., Darley, J. M., \& Cohen, J. D. (2001), An AMRI investigation of emotional engagement in moral judgment. Science, 293, 2105-2108.

Harrison, J. L. (1986). Egoism, altruism, and market illusions: The limits of law and economics. UCLA Law Review, 33, 1309-1363.

Hartman, R. G. (2008). Gault's legacy: Dignity, due process, and adolescents' liberty interests in living donation. Notre Dame Journal of Law, Ethics \&u Public Policy, 22, 67-106.

Henderson, A. J. Z., Landolt, M. A., McDonal, M. F., Barrable, W. M., Soos, J. G., Gourlay, W., et al. (2003). The living anonymous kidney donor: Lunatic or saint? American Journal of Transplantation, 3, 203-213.

Hernandez, P. M. (2003). The myth of machismo: An everyday reality for Latin American women. Saint Thomas Law Review, 15, 859-882.

Hernandez- Truyol, B. E. (2008). The gender bend: Culture, sex, and sexuality-a critical human rights map of Latina/o border crossing. Indiana Law Journal, 83, 1283-1331.

Hernandez, P. M. (2003). The myth of machismo: An everyday reality for Latin American women. Saint Thomas Law Review, 15, 859-882.

Hoeffel, J. C. (2006). Deconstructing the cultural defense debate. University of Florida Journal of Law and Public Policy, 17, 303-344.

Jansen, L. A. (2009). The ethics of altruism in clinical research. Hastings Center Report, 39, 26-36.

Johns, A. F. (2004). Older clients with diminishing capacity and their advance directives. Real Property, Probate \& Trust Journal, 39, 107-134.

Judd, T. (2005). Cross-cultural forensic neuropsychological assessment. In K. Barrett, \& W. George (Eds.), Race, culture, psychology and law (pp. 141-162). Thousand Oaks, CA: Sage Publications. 
Kahn, M. (2002). Jurisprudential countertransference. Touro Law Review, 18, 459-477.

Kell, W. A. (1998). Ties that bind? Children's attorneys, children's agency, and the dilemma of parental affiliation. Loyola University Chicago Law Journal, 29, 353-376.

King, M. (2009). Restorative justice, therapeutic jurisprudence and the rise of emotionally intelligent justice. Research Paper No. 2009/11, Faculty of Law, Monash University, Victoria, AU. Retrieved from http://ssrn.com/abstract=no.1498923=

King, N. A. (1999). The role of culture in psychology: A look at mental illness and the "cultural defense." Tulsa Journal of Comparative \& International Law, 7, 199-225.

Kivivuori, J. (2007). Crime by proxy: Coercion and altruism in adolescent shoplifting. British Journal of Criminology, 4, 817-833.

Knabb, J. J., Welsh, R. K., Ziebell, J. G., \& Reimer, K. S. (2009). Neuroscience, moral reasoning, and the law. Behavioral Sciences and the Law, 27, 219-236.

Knafo, A., Israel, S., Darvasi, A., Bachner-Melman, R., Uzefovsky, F, Cohen, L, et al, (2007). Individual differences in allocation of funds in the dictator game associated with length of the arginine vasopressin la receptor RS3 promoter region and correlation between RS3 length and hippocampal mRNA. Genes, Brain and Behavior, 7, 266-275,

Knafo, A. et al (2009) Heritability of children's prosocial behavior and differential susceptibility to parenting by variation in the Dopamine D4 Receptor (DRD4) gene. (Submitted to Development and Psychopathology special issue on differential susceptibility to environmental influences.)

Kuklin, B. (2008). The morality of evolutionarily self-interested rescues. Arizona State Law Journal, 40, 453-521.

Landolt, M. A., Henderson, A. J., Barrable, W. M., Greenwood, S.D., McDonald, M.F., Soos, J. G., and Landsberg, D.N. (2001). Living anonymous kidney donation: What does the public think? Transplantation, 71, 1690-1696.

Landsman, M. \& McNeel, S. P. (2004). Moral judgment of law students across three years: Influences of gender, political ideology and interest in altruistic law practices. South Texas Law Review, 45, 891-919.

Lee, C. (2007). Cultural convergence: Interest convergence theory meets the cultural defense. Arizona Law Review, 49, 911-959.

Lewis, C. F. \& Bunce, S. C. (2003). Filicidal mothers and the impact of psychosis on maternal filicide. Journal of the American Academy of Psychiatry of Law, 31, $459-470$.

Li, J. (1996). The nature of the offense: An ignored factor in determining the application of the cultural defense. University of Hawaii Law Review, 18, 765-796.

Linford, J. (2009). The kidney donor scholarship act: How college scholarships can provlde financial incentives for kidney donation while preserving altruistic meaning. St. Louis University Journal of Health Law and Policy, 2, 265-325.

Luber, B., Fisher, C., Appelbaum, P. S., Ploesser, M., \& Lisanbyet, S. H. (2009). Noninvasive brain stimulation in the detection of deception. Scientific challenges and ethical consequences. Behavioral Sciences \& Law, 27, 191-208.

Maguigan, H. (1995). Cultural evidence and male violence: Are feminist and multiculturalist reformers on a collision course in criminal courts? New York University Law Review, 70, 36-99.

Marks, J. H. (2007). Interrogational neuroimaging in counterterrorism: A "no-brainer" or human rights hazard, American Journal of Law and Medicine, 33, 483-502.

McClain, L. C. (1999). The liberal future of relational feminism: Robin West's "Caring for Justice." Law o Social Inquiry, 24, 477-516.

McClain, L. C. (2001). Care as a public value: Linking responsibility, resources, and republicanism. Chicago-Kent Law Review, 76, 1673-1731. 
McWilliams, N. (1984). The psychology of the altruist. Psychoanalytic Psychology, 1, 193-213.

Menkel-Meadow, C. (1992). Is altruism possible in lawyering? Georgia State University Law Review, 8, 385-419.

Miller, D. (2009). Applying therapeutic jurisprudence and preventive law to the divorce process: Enhancing the attorney-client relationship and the Florida practice and procedure form "Marital settlement agreement for dissolution of marriage with dependent or minor child(ren)." Florida Coastal Law Review, 10, 263-297.

Moriarty, J. (2008). Flickering admissibility: Neuroimaging in the U.S. courts, Behavioral Sciences \& Law, 26, 29-49.

Mueller, P. S., Case, E. J., \& Hook, C. C. (2008). Responding to offers of altruistic living unrelated kidney donation by group associations: An ethical analysis. Transplantation Reviews, 22, 200-205.

Muller, J. L., Sommer, M., Dohnel, K, Weber, T., Schmidt-Wilcke, T., \& Hajak, G. (2008). Disturbed prefrontal and temporal brain function during emotion and cognition interaction in criminal psychopathy, Behavioral Sciences and the Law, 26, 131-150.

Note (1986). The cultural defense in the criminal law. Harvard Law Review, 99, 1293-1311. (Harvard Note).

Oberman, M. (2004). Mothers who kill: Coming to terms with modern American infanticide. DePaul Journal of Health Care Law, 8, 3-107.

Parker, R. (2004). Brain rewards for carrying out altruistic punishment. FuturePundit: Brain Altruism Archives. Retrieved from http://www.futurepundit.com.archives.cat_ brain_altruism.html

Parker, R. (2007). Altruistic people differ in brain scans. FuturePundit: Brain Altruism Archives, Retrieved from http://www.futurepundit.com.archives.cat_brain_altrulsm. html

People v. Kimura, No. A-091133 (Cal. Sup Ct., LA County, April 24, 1985).

People v. Moua, No. 315972-0 (Cal. Super. Ct. Fresno County Feb. 7, 1985).

People v. Wu, 286 Cal. Rptr. 868 (App. 1991) (depublished).

Perlin, M. L. (1994). The sanist lives of jurors in death penalty cases: The puzzling role of "mitigating" mental disability evidence. Notre Dame Journal of Law, Ethics of Public Policy, 8, 239-279.

Perlin, M. L. (1997). "The borderline which separated you from me": The insanity defense, the authoritarian spirit, the fear of faking, and the culture of punishment. Iowa Law Review, 82, 1375-1426.

Perlin, M. L. (1999). "Half-wracked prejudice leaped forth": Sanism, pretextuality, and why and how mental disability law developed as it did. Journal of Contemporaty Legal Issues, 3, 14-36.

Perlin, M. L. (2000). A law of healing. University of Cincinnati Law Review, 68, 407-433.

Perlin, M. L. (2002-2003). "Things have changed": Looking at non-institutional mental disability law through the sanism filter,New York Law School Law Review, 46, 535-546.

Perlin, M. L. (2003). "She breaks just like a little girl": Neonaticide, the insanity defense, and the irrelevance of ordinary common sense. William o Mary Journal of Women and Law, 10, 1-34.

Perlin, M. L. (2005). "And my best friend, my doctor, won't even say what it is I've got": The role and significance of counsel in right to refuse treatment cases. San Diego Law Review, 42, 735-755.

Perlin, M. L. (2008). "Everybody is making love/or else expecting rain": Considering the sexual autonomy rights of persons institutionalized because of mental disability in forensic hospitals and in Asia. University of Washington Law Review, 83, 481-508. 
Perlin, M. L. (2009a). A therapeutic jurisprudence inquiry into the roles of dignity and humiliation in the law. Human Dignity and Humiliation Studies. Retrieved from http:/ www.humiliationstudies,org/whoweare/annualmeeting14.php

Perlin, M. L. (2009b), "His brain has been mismanaged with great skill": How will jurors respond to neuroimaging testimony in insanity defense cases? Akron Law Review, 42, 885-916.

Perlin, M. L. (2009c). "And I see through your brain": Access to experts, competency to consent, and the impact of antipsychotic medications in neuroimaging cases in the criminal trial process. Stanford Technology Law Journal, 2009, 4.

Perlin, M. L. (2010). "Too stubborn to ever be governed by enforced insanity": Some therapeutic jurisprudence dilemmas in the representation of criminal defendants in incompetency and insanity cases. International Journal of Law and Psychiatry, 33, 475-481.

Perlin, M. L., \& Cucolo, H. E. (2009 Cum. Supp.). Mental disability law: Civil and criminal Vol. 1 (2nd ed.). Newark, NJ: Lexis-Nexis Publ.

Perlin, M. L., \& McClain, V. (2009a). Unasked (and unanswered) questions about the role of neuroimaging in the criminal trial process. American Journal of Forensic Psychology, $28,5-22$.

Perlin, M. L., \& McClain, V. (2009b). "Where souls are forgotten”: Cultural competencies, forensic evaluations, and international human rights. Psychology, Public Policy ob Law, $15,257-277$.

Perlmutter, B. (2005). George's story: Voice and transformation through the teaching and practice of therapeutic jurisprudence in a law school child advocacy clinic. Saint Thomas Law Review, 17, 561-621.

Petrila, J. (1993). Paternalism and the unfulfilled promise of "Essays In Therapeutic Jurisprudence." New York Law School Journal of Human Rights, 10, 877-905.

Power, H. (2007). Pitcairn Island: Sexual offending, cultural difference and ignorance of the law. Criminal Law Review, 609-629.

Reeves, D., Mills, M. J., Billick, S. B., \& Brodie, J. D. (2003). Limitations of brain imaging in forensic psychiatry. Journal of the American Academy of Psychiatry and the Law, 31, 89-96.

Renteln, A. D. (1993). A justification of the cultural defense as partial excuse. Southern California Review of Law of Womer's Studies, 2, 437-526.

Renteln, A.D. (2004). The use and abuse of the cultural defense. Canadian Journal of Law and Soclety, 20, 47-67.

Rilling, J. K. (2008). Neuroscientific approaches and applications within anthropology, Yearbook of Physical Anthropology, 51, 2-32.

Rilling, J, K. (2009). The neurobiology of cooperation and altruism. Context and the evolution of mechanisms for solving collective action problems. Paper, Indiana University. Retrieved from http://ssm.com/abstract=1368881

Risinger, D. M. (2000). Navigating expert reliability: Are criminal standards of certainty being left on the dock? Albany Law Review, 64, 99-152.

Roberts, A. (2007). Everything new is old again: Brain fingerprinting and evidentiary analogy. Yale Journal of Law b Technology, 9, 234-272.

Ronel, N., Haski-Leventhal, D., Ben-David, B. M., \& York, A. S. (2009), Perceived altruism: A neglected factor in initial intervention. International Journal of Offender Therapy o Comparative Criminology, 53, 191-209.

Ronner, A. (2002). Songs of validation, voice, and voluntary participation: Therapeutic jurisprudence, Miranda and juveniles. University of Cincinnati Law Review, 71, 89-120.

Ronner, A. (2008). The learned-helpless lawyer: Clinical legal education and therapeutic jurisprudence as antidotes to Bartleby syndrome. Touro Law Review, 24, 601-664. 
Ronner, A. (2010). Law, literature and therapeutic jurisprudence. (Durham, NC: Carolina Academic Press).

Rotman, E. (2008). Therapeutic jurisprudence and terrorism. Thomas Jefferson Law Review, 30, 525-545.

Rozelle, S. (2007). Daubert, Schmaubert: Criminal defendants and the short end of the science stick. Tulsa Law Review, 43, 597-606.

Ruel, M. D. (2007). "Vanity tax": How New Jersey has opened Pandora's box by elevating its moral judgment about cosmetic surgery without consideration of fair health care policy. Journal of Legal Medicine, 28, 119-134.

Rushton, J. P. (1989). Genetic similarity, human altruism, and group selection. Behartoral and Brain Sciences, 12, 503-559.

Salisbury, C. S. (2005). From violence and victimization to voice and validation: Incorporating therapeutic jurisprudence in a children's law clinic. Saint Thomas Law Review, 17, 623-676.

Schreiber, D., et al. (September, 2009). Red brain, blue brain: Evaluative processes differ in democrats and republicans. Paper presented at the American Political Science Association, Toronto, ON. Retrieved from http://papers.ssrn.com/Sol3/papers. cfm?abstract_id=1451867

Schwartz, C., Meisenhelder, J. B., Ma, Y, \& Reed, G. (2003). Altruistic social interest behaviors are associated with better mental health. Psychosomatic Medicine, 65, 778-785.

Seelig, B. J., \& Rosof, L. S. (2001). Normal and pathological altruism. Journal of the American Psychoanalytic Association, 49, 933-959.

Seymour, B., Singer, T., \& Dolan, R. (2007). The neurobiology of punishment, Nature Reviews Neuroscience, 8, 300-311.

Shapiro, Y., \& Gabbard, G. O. (1994). A reconsideration of altruism from an evolutionary and psychodynamic perspective. Ethics b Behavior, 4, 23-42.

Sheehan, K. C. (2000). Caring for deconstruction. Yale Journal of Feminism, 12, 85-142.

Shiraf, M. (2008). "Justice in Many Rooms" since Galanter: De-romanticizing legal pluralism through the cultural defense. Law and Contemporary Problems, 71, 139-146.

Shirtcliff, E. A., Vitacco, M. J., Graf, A, R., Gostisha, A. J., Merz, J. L., \& Zahn-Waxler, C. (2009). Neurobiology of empathy and callousness: Implications for the development of antisocial behavior. Behavioral Sciences and the Law, 27, 137-171.

Shuman, D. W. (1993). Making the world a better place through tort law? Through the therapeutic looking-glass. New York Law School Journal of Human Rights, 10, 739-752.

Siegel, A., \& Victoroff, J. (2009). Understanding human aggression: New insights from neuroscience, International Journal of Law and Psychiatry, 29, 209-215.

Silverman, H. (1997). The role of emotions in decisional competence, standards of competency, and altruistic acts. Journal of Clinical Ethics, 8, 171-175.

Slobogin, C. (1995). Therapeutic jurisprudence: Five dilemmas to ponder. Psychology, Public Policy of Law, 1, 193-219.

Snead, O. C. (2007). Neuroimaging and the "complexity" of capital punishment. New York University Law Review, 82, 1265-1337.

Spike, J. (1997). What's love got to do with it? The altruistic giving of organs. Journal of Clinical Ethics, 8, 165-170.

Spital, A. (2001). Public attitudes toward kidney donation by friends and altruistic strangers in the United States. Transplantation, 71, 1061-1064.

Stolle, D. P., Wexler, D. B. \& Winick, B. J. (2000). Practicing therapeutic jurisprudence: Law as a helping profession. Durham, NC: Carolina Academic Press.

Stout, L. A. (2002). Judges as altruistic hierarchs. William \& Mary Law Review, 43, 1605-1627. 
Sullivan, D. A. (2000) Cosmetic surgery: The cutting edge of commercial medicine in America. New Brunswick, NJ: Rutgers University Press.

Suri, S. K. (2000). A matter of principle and consistency: Understanding the battered woman and cultural defenses. Michigan Journal of Gender and Law, 7, 107-139.

Tankersley, D., Stowe, C. J., \& Huettel, S. A. (2007). Altruism is associated with an increased neural response to agency. Nature Neuroscience, 10, 150-151.

Tovino, S. (2007). Functional neuroimaging information: A case for neuro exceptionalism? Florida State University Law Review, 34, 415-486.

Uttal, W. (2003). The new phrenology: The limits of localizing cognitive processes in the brain. London, UK: The MIT Press.

Villareal, C. (1991). Culture in lawmaking: A Chicano perspective. University of California Davis Law Review, 24, 1193-1242.

Volpp, L. (1994). (Mis)identifying culture: Asian women and the "cultural defense". Harvard Women's Law Journal, 17, 57-101.

Waldman, E. (2008). Therapeutic jurisprudence: Growing up and looking forward. Thomas Jefferson Law Review, 30, 345-349.

Wang, K. (1996). Battered Asian American women: Community responses from the battered women's movement and the Asian American community. Asian Law Journal, $3,151-184$.

West, R. (1997). Caring for justice. New York City: New York University Press.

Wexler, D. B. (Ed.). (1990). Therapeutic jurisprudence: The law as a therapeutic agent. Durham, NC: Carolina Academic Press.

Wexler, D. B. (1993). Therapeutic jurisprudence and changing concepts of legal scholarship. Behavioral Sciences \& Law, 11, 17-29.

Wexler, D. B. (2000). Practicing therapeutic jurisprudence: Psycholegal soft spots and strategies. In D. P. Stolle, D. B. Wexler, \& B. J. Winick (Eds.), Practicing therapeutic jurisprudence: Law as a helping profession (pp. 45-68). Durham, NC: Carolina Academic Press.

Wexler, D. B. (2008). Rehabilitating lawyers: Principles of therapeutic jurisprudence for criminal law practice. Durham, N.C.: Carolina Academic Press.

Wexler, D. B. (2008). Two decades of therapeutic jurisprudence. Touro Law Review, 24, 17-28.

Wexler, D. B. \& Winick, B. J. (Eds.). (1996). Law in a therapeutic key: Recent developments in therapeutic jurisprudence. Durham, NC: Carolina Academic Press.

Wilson, L. T. (2007). The beloved community: The influence and legacy of personalism in the quest for housing and tenant's rights. John Marshall Law Review, 40, 513-538.

Winick, B. J. (1998), Foreword: Planning for the future through advance directive instruments, Psychology, Public Policy b Law, 5, 579-608.

Winick, B. J. (1999). Therapeutic jurisprudence and the civil commitment hearing. Journal of Contemporary Legal Issues, 10, 37-56.

Winick, B. J. (2002). Therapeutic jurisprudence and the treatment of people with mental illness in Eastern Europe: Construing international human rights law, New York Law School Journal of International do Comparative Law, 21, 537-572.

Winick, B. J. (2003). Therapeutic jurisprudence and problem solving courts. Fordham Urban Law Journal, 30, 1055-1084.

Winick, B. J. (2005). Civil commitment: A therapeutic jurisprudence model. Durham, NC: Carolina Academic Press.

Winick, B. J. (2009). Foreword: Therapeutic jurisprudence perspectives on dealing with victims of crime. Nova Law Revtew, 33, 535-541. 
Witzel, J., Walter, M., Bogerts, B., \& Northoff, G. (2008). Neurophilosophical perspectives of neuroimaging in forensic psychiatry-giving way to a paradigm shift? Behavioral Sciences and the Law, 26, 113-130.

Wu, M. W. C. (2003). Culture is no defense for infanticide. American University Journal of Gender, Social Policy, and the Law, 11, 975-1022.

Yuille, L. K. (2007). Nobody gives a damn about the gypsies: The limits of Westphalian models for change. Oregon Review of International Law, 9, 389-430. 
Witzel, J., Walter, M., Bogerts, B., \& Northoff, G. (2008). Neurophilosophical perspectives of neuroimaging in forensic psychiatry-giving way to a paradigm shift? Behavioral Sciences and the Law, 26, 113-130.

Wu, M. W. C. (2003). Culture is no defense for infanticide. American University Journal of Gender, Social Policy, and the Law, 11, 975-1022.

Yuille, L. K. (2007). Nobody gives a damn about the gypsies: The limits of Westphalian models for change. Oregon Review of International Law, 9, 389-430. 